\title{
Mechanisms and pathobiology of ovulation
}

\author{
WJ Murdoch, CJ Murphy, EA Van Kirk and Y Shen \\ Reproductive Biology Program, University of Wyoming, Laramie, WY USA 82071
}

The ovulatory process is extraordinary in that it constitutes a hormoneinduced injury. Gonadotropin delivered via the follicular vascular wreath stimulates secretion of plasminogen activator by contiguous ovarian surface epithelial cells. A consequent elevation in interstitial plasmin activates collagenases and cleaves tumor necrosis factor $\alpha$ from its anchors on endothelium. Collagen fibril degradation and cellular death at the apex of the preovulatory follicle are hallmarks of impending ovulation. Follicular contractions rupture the weakened fabric at the apex, and the ovum, which has been disconnected from the underlying granulosa, is expelled; these components of the cascade are prostaglandin-mediated. Ovulation is required for fertility; unfortunately, it imparts a cancer risk to the ovarian surface epithelium. DNA-damaging reactive oxygen species are generated by inflammatory cells attracted into the vicinity of the ovulatory stigma. An ischemia-reperfusion flux coincident with ovulation and wound repair also contributes to genotoxicity. Potentially mutagenic lesions in DNA are normally reconciled by TP53 tumor suppressor-dependent cell-cycle arrest and base excision repair mechanisms; it is a unifocal escape that could be problematic. Epithelial ovarian cancer is a deadly insidious disease because it typically remains asymptomatic until it has metastasized to vital abdominal organs.

\section{Introduction}

A follicle recruited to ovulate emerges along the ovarian cortex and comes into apposition with the surface epithelium. The initiating signal for ovulation is the surge in secretion of luteinizing hormone $(\mathrm{LH})$ that occurs during the late follicular phase. Proteolytic enzymes and inflammatory mediators liberated at the follicular-ovarian surface interface degrade collagen matrices and provoke cellular death. Follicular contractions facilitate rupture and ovum expulsion (Murdoch, 2000).

More than $90 \%$ of cancers of the ovary are thought to arise from the surface epithelium. Circumstances that avert ovulation protect against epithelial ovarian cancer (Bandera, 2005). Damages to DNA caused by oxyradicals are a major cause of cancer (Valko et al., 2004). Indeed, reactive oxygen species produced during the periovulatory period compromise the DNA integrity of bystander ovarian surface cells. These cells proliferate and migrate to mend the void in the ovarian epithelium created by ovulation. It is conceivable that clonal expansion of a cell with unrepaired DNA is an initiating factor in the etiology of ovarian cancer (Murdoch, 2008). Early-stage disease is characterized by formation of an inclusion cyst which contains surface epithelial cells that have invaded the ovary (Feeley and Wells, 2001). Apparently the

Corresponding author E-mail: wmurdoch@uwyo.edu 
microenvironment of the inclusion is conducive to metaplastic changes that precede cancer. Malignant cells seed the abdominal cavity when a cyst ruptures. A mutant cell exfoliated during the mechanics of ovulation may account for cases of diffuse intraperitoneal disease in which the ovaries remain relatively uninvolved (Hamilton, 1992).

Objectives of this chapter are to provide overviews of the mechanisms and carcinogenic implications of ovulation with an emphasis on research using an ovine model.

\section{Experimental paradigm}

Mature western-range ewes were penned with vasectomized rams and observed for standing estrus (Day 0). Animals were treated on Day 14 with prostaglandin (PG) $F_{2} \alpha$ to synchronize luteal regression. An agonistic analog of gonadotropin-releasing hormone $(\mathrm{GnRH})$ was administered $36 \mathrm{~h}$ after $\mathrm{PGF}_{2} \alpha$ to elicit a preovulatory surge of $\mathrm{LH}$. The dominant follicle within the pair of ovaries will consistently ovulate approximately $24 \mathrm{~h}$ after $\mathrm{GnRH}$ and form a normal corpus luteum. A translucent stigma develops within $2 \mathrm{~h}$ of ovarian rupture (Roberts et al., 1985).

\section{Ovulation: Proteolytic enzymes and tumor necrosis factor}

Interstitial (type I) collagen constitutes the primary connective tissue component of the follicular theca and tunica albuginea. Basement membranes that circumscribe thecal capillary beds and support mural granulosa and ovarian surface cells are composed of type IV collagen (Luck, 1994). Fibrillar collagens are comprised of three polypeptide chains coiled into a helix; nascent $\alpha$-chains consist of repeating triplets of glycine-X-Y, where $X$ and $Y$ are often proline or hydroxyproline (Shoulders and Raines, 2009). Type IV collagen forms a flexible mesh-like scaffold to which matrix constituents (laminin, entactin, perlecan) and epithelial cells attach (LeBleu et al., 2007). Collagen breakdown within the apex of the preovulatory follicle is predictive of ovulation.

Two principal families of enzymes, plasminogen activators/plasmin and matrix metalloproteinases (MMPs), govern tissue dissolution during ovulation. Plasmin (fibrinolysin) is a pleiotropic serine protease that is derived from its zymogen by enzymatic activation. Two forms of plasminogen activator (PA) have been characterized in vertebrates: urokinase $(\mathrm{U})$ and tissue ( $\mathrm{t}$ ) types. Most studies indicate that uPA mediates tissue degradation and carcinogenesis, whereas IPA (that has an affinity for fibrin) modulates thrombolysis (Andreasen et al., 2000). Collectively the zinc/calcium-dependent MMPs $(n \geq 28)$ degrade collagens, elastin, proteoglycans, and adhesion molecules. Classical mammalian collagenases truncate each of the polypeptide chains of fibrillar collagens at sites near the carboxyl end (3/4, 1/4 fragments). Matrix metalloproteinases share many structural and functional attributes but differ somewhat in substrate specificities. Types I and IV collagens are the prototype substrates for types I (MMP-1) and IV (MMP-2, gelatinase A; MMP-9, gelatinase B) collagenases. Matrix-degrading effects of metalloproteinases depend upon de novo production, proteolytic activation, and endogenous tissue inhibitor concentrations. Excision of latent collagenases (e.g., by plasmin), permitting a second autolytic cleavage of the Cys- $\mathrm{Zn}^{2 *}$ bond that stabilizes the propeptide, exposes the catalytic domain of the enzyme. Tissue inhibitors of MMPs (TIMPs 1-4), which noncovalently interact on a 1:1 stoichiometric basis with enzymatic substrate-binding sites, limit the degree of extracellular damage that otherwise would be inflicted by untempered proteolysis (Nagase and Woessner, 1999).

Sheep ovarian surface epithelial cells secrete uPA toward the tunica albuginea and apical follicular wall in response to $\mathrm{LH}$. Receptors for $\mathrm{LH}$ on ovarian surface cells are up-regulated 
at proestrus by estradiol of preovulatory follicular origin (Murdoch et al., 1999a). Ovarian epithelium in close proximity to the preovulatory follicle is exposed to surge concentrations of $\mathrm{LH}$ due to an acute histamine-mediated increase (4-12 h after $\mathrm{GnRH}$ ) in permeability of and blood flow through the thecal vascular wreath (Halterman and Murdoch, 1986; Cavender and Murdoch, 1988).

An increase in plasmin within the apical hemisphere of preovulatory ovine follicles at 12 $h$ after GnRH was attributed to secretion of uPA by ovarian surface epithelial cells (tPA was undetectable). When ovarian surface epithelium was removed surgically at $8 \mathrm{~h}$ following $\mathrm{GnRH}$ treatment, the follicular rise in UPA and ovarian rupture were negated. Furthermore, ovulation was suppressed by intrafollicular injection of uPA (but not tPA) antibodies at $8 \mathrm{~h}$ (Colgin and Murdoch, 1997) or $\alpha_{2}$-antiplasmin at $16 \mathrm{~h}$ (Murdoch, 1998a) after GnRH. Plasminogen activators also were increased within the apices of preovulatory porcine (Smokovitis et al, 1988) and rat (Peng et al., 1993) follicles. Both uPA and tPA contribute to ovarian plasmin production and ovulatory efficiency in rodents (Hagglund et al, 1996).

Collagenolysis was associated with apical accumulation of plasmin in preovulatory ovine follicles (Murdoch and McCormick, 1992). Explants of follicular wall released hydroxyprolinecontaining peptides (degraded collagen) after exposure to plasmin and injection of antiplasmin into preovulatory follicles repressed collagenase bioactivity of tissue extracts. The effect of plasmin on collagen breakdown was not transcription-dependent, but rather was related to proenzyme activation (Murdoch, 1998a). Collagenolysis also was elevated preferentially within the apex of preovulatory human follicles (Fukumoto et al., 1981). Morphological observations indicate that preovulatory connective tissue disruption begins at the ovarian surface and advances inward to encompass the apical follicular wall (Bjersing and Cajander, 1975; Talbot et al., 1987). Tunica/thecal fibroblasts and follicular steroidogenic (theca, granulosa) cells are sources of procollagenases (Tadakuma et al., 1993). General chemical inhibitors of collagenases suppressed ovulation in rodents (Reich et al., 1985; Butler et al., 1991). Mice with a mutation in the type I collagen gene, conferring resistance to collagenase, are infertile due to anovulation (Liu et al, 1995).

Tumor necrosis factor (TNF) $\alpha$, by promoting collagenase gene expression and (at relatively higher concentrations) cellular death, is an intermediary of ovulation. The precursor cytokine is a transmembrane protein that upon cleavage yields a bioactive extracellular subunit. Mature (soluble) TNF $\alpha$ is a noncovalent homotrimer. Target tissue effects of TNF $\alpha$ are receptor subtype- and concentration-dependent. Plasma membrane glycoprotein receptors for TNF $\alpha$ (RI, RII) are present on virtually all nucleated cells. Receptors bind trimeric ligand through a homologous extracellular amino terminal motif. The cytoplasmic segment of TNFRI contains a death domain that upon receptor aggregation can evoke a caspase cascade leading to apoptotic (internucleosomal) DNA fragmentation and pyknosis. Nonlethal transcriptional events (to include collagenase gene up-regulation) also can be activated by TNFRI and TNFRII ligation. It remains unclear what mechanisms dictate pathways of signal transduction outcome - toward genomic stimulation with or without programmed death. At high tissue concentrations, TNF $\alpha$ initiates microvascular coagulation associated with necrotic cellular death and acute inflammation (Larrick and Wright, 1990; Baker and Reddy, 1996).

Tumor necrosis factor $\alpha$ was localized to thecal endothelial cells of preovulatory ovine follicles by fluorescence microscopy. Immunostaining of endothelium within the follicular apex declined abruptly with the approach of ovulation (cells within the counterpart basal wall were unaffected). Plasmin truncated TNF $\alpha$, releasing it into the site of rupture (Murdoch et al., 1997, 1999). Preovulatory follicles of other species (rat, bovine, human) also secrete TNF $\alpha$ (Terranova, 1997; deMola et al., 1998). Urokinase and basement membrane-degrading MMPs were secreted 
from human ovarian surface epithelial cells stimulated by TNF $\alpha$ (Yang et al., 2004). Human TNF $\alpha$ is liberated from cells by a metalloproteinase disintegrin (Black et al., 1997).

Types I and IV collagenases were induced in sheep follicular tissues by TNF $\alpha$; these responses were abrogated by the transcriptional inhibitor actinomycin D (Johnson et al., 1999; Gottsch et al., 2000). Therefore, it appears that TNF $\alpha$ potentiates ovulatory collagenolysis by assuring that sufficient quantities of (pro) MMPs are synthesized. Intrafollicular injection of TNF $\alpha$ antibodies at 10-12 h after GnRH inhibited collagen degradation (Johnson et al., 1999) and blocked ovulation (Murdoch et al., 1997). Moreover, progressive (16-24 h post-GnRH) increases in apoptotic and necrotic cells within the ovarian surface epithelium, tunica albuginea, and apical follicular wall were nullified by immunoneutralization of TNF $\alpha$ (Murdoch 1994, 1995a,b; Murdoch et al., 1997, 1999b). Secretion into the follicular fluid of low (nonlethal) concentrations of TNF $\alpha$ by the oocyte-cumulus complex facilitated collagen breakdown throughout the follicular wall (Johnson et al., 1999). Microinjection of high concentrations of TNF $\alpha$ into the apical wall of explanted sheep follicles (to mimic the local extracellular milieu near ovulation) provoked stigma development (Murdoch et al., 1999b). Addition of TNF $\alpha$ to perfusates of rat ovaries enhanced ovulation rates elicited by $\mathrm{LH}$ (Brannstrom et al., 1995). Ovulation occurred in TNF $\alpha$ RI knockout mice during the peripuberal period; however, ovarian cyclicity was disrupted by 6 months of age (the peak in reproductive performance) (Roby et al., 1999). Tumor necrosis factor $\alpha$-induced hyaluronate-binding protein- 6 was expressed in preovulatory rat (Yoshioka et al., 2000), equine (Sayasith et al., 2007), and porcine (Nagyova et al., 2009) follicles.

Net proteolysis during ovulation is controlled by relative balances of enzymes to inhibitors. In theca of periovulatory rat follicles membrane type 1-MMP activates pro-MMP-2 by complexing with TIMP-2 (Jo et al., 2004). Increased production of TIMP-1 and $\alpha_{2}$-macroglobulin by granulosa cells serves to confine the extent of ovulatory tissue destruction and assure that a viable corpus luteum can be formed (Curry and Smith, 2006).

\section{Ovulation: Progesterone and prostaglandins}

During the preovulatory period, steroidogenic function of the follicle shifts from an estrogen- to progesterone-producing gland. It has been recognized for many years that the rise in progesterone is more than just an index of transition toward the luteal phase. Inhibitors of progesterone biosynthesis/ action suppress ovulation (Zalanyi, 2001). That inhibition of follicular prostaglandin (PG) production (by nonsteroidal antiinflammatory agents, most notably indomethacin) inhibits ovulation also is well established. Progesterone and prostaglandins have been implicated as effectors of collagenase production (Murdoch et al., 1986, 1993).

A marked increase in progesterone in preovulatory ovine follicles occurred at $16 \mathrm{~h}$ after $\mathrm{GnRH}$. The initial rise in prostaglandin production at $8 \mathrm{~h}$ favored $\mathrm{PGE}_{2}$. Prostaglandin $\mathrm{E}_{2}$ mediates losses in contacts among mural granulosa and cumulus cells (Murdoch, 1988). Progesterone subsequently induces 9-ketoreductase, which converts PGE to PGF $\alpha$ (Murdoch and Farris, 1988). Prostaglandin $F_{2} \alpha$ stimulates contractile elements within the theca externa (Murdoch et al., 1993). Expressions throughout the bovine follicular wall of prostaglandin receptors predict diverse actions in the ovulatory cascade (Bridges and Fortune, 2007).

\section{Ovulatory mechanisms: Model and additional considerations}

An integrative scheme is presented (Figure 1) whereby; 1) gonadotropic stimulation of uPA secretion by ovarian surface epithelial cells conjoined with the preovulatory follicle elicits a localized increase in tissue plasmin, which activates latent collagenases and releases TNF $\alpha$ from its anchors along thecal endothelium; 2) soluble TNF $\alpha$ augments collagenolysis by induction of MMP gene expression and 
causes epithelial/vascular dissolution; 3) progesterone and prostaglandins facilitate collagenolysis and mediate oocyte delivery to the ovarian surface; 4) weakening of the apical follicular wall leads to stigma formation and ovarian rupture; 5) collagen remodeling, migration of interstitial cells, and neovascularization during differentiation of the sheep corpus luteum were dependent upon TNF $\alpha$ induced MMP-2 production (Gottsch et al., 2000).

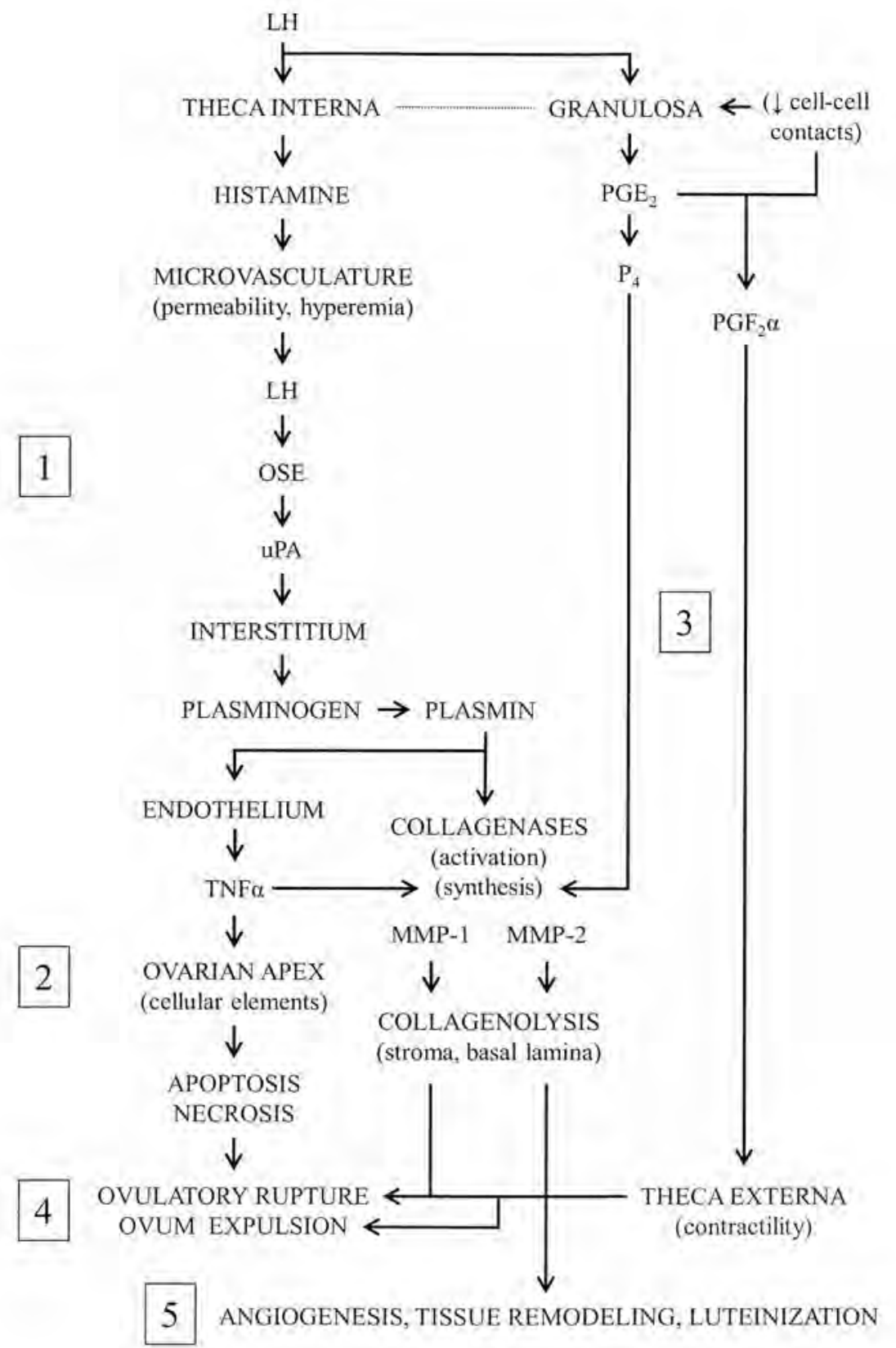

Fig. 1. Sequences of events dictating the ovulatory folliculo-luteal transition in the ewe. OSE, ovarian surface epithelium. $P_{4}$, progesterone. See text for explanations (1-5). 
Proteases other than PAs/plasmin, MMP-1, and MMP-2 are potential regulators of ovulation. Matrix metalloproteinase-9 was elevated in fluid of preovulatory follicles of pigs (Driancourt et al., 1998) and horses (Riley et al., 2001). Collagenase-3 (MMP-13), which degrades collagens IIII, was increased in preovulatory rat follicles (Balbin et al., 1996; Komar et al., 2001). Cathepsin $\mathrm{L}$, a lysosomal cysteine protease member of the papain family, and ADAMTS-1, a disintegrin and metalloproteinase with thrombospondin-like motifs, were induced in preovulatory follicles of rodents. Mice with a mutant progesterone receptor gene, which failed to ovulate, expressed MMP-2, -9, and -13 upon gonadotropic stimulation, however, mRNAs encoding cathepsin L and ADAMTS-1 were reduced (Robker et al., 2000). Anovulation in a rat polycystic ovarian disease model has been related to increased expression of a lysyl oxidase that initiates crosslink formation of collagen and elastin (Endo et al., 2001).

Thromboxanes and lipoxygenase products of arachidonate catabolism also have been implicated in the mechanisms of ovulation (Carvalho et al, 1989; Wilken et al., 1990). Functional cyclooxygenase and lipoxygenase pathways overlapped in a murine model of ovulation (Kurusu et al., 2009).

\section{Ovulation-cancer connection: Circumstantial evidence}

Common (surface epithelial) cancer of the ovary is an ovulation-related disease. Inhibition of ovulation conferred by oral contraceptive use, pregnancy, and lactation safeguard against ovarian cancer (Bandera, 2005).

An ovulation-cancer hypothesis was first proposed by Fathalla in 1971, who suggested that "incessant" ovulations (without intervening dormant periods afforded by pregnancy) caused transformation of the ovarian epithelium. Exposure to estrogen-rich follicular fluid and injury were suspected causes.

Positive correlations among lifetime ovulations, ovarian precursor lesions, and carcinoma have been documented for women. In one analysis (Purdie et al., 2003) there was a 6\% increase in cancer risk with each ovulatory year. It appears that the most aggressive/damaging ovulations occur during the peak reproductive years and that ovulations have a more significant impact in premenopausal- than postmenopausal-onset ovarian cancer (Tung et al, 2005).

Assisted reproductive programs that implement ovulation-inducing protocols would presumably increase the carcinogenic risk. Yet data relating use of fertility drugs to ovarian cancer have been inconclusive. Some have concluded that women who do not become pregnant and are subjected to multiple treatments are at an elevated risk, while others suggest weak or no significant correlations (Mahdavi et al., 2006; Chene et al., 2009). Overall rates of ovarian cancer have remained relatively constant despite the widespread application of ovulatory stimulants. Because the latency between initiation (at ovulation) and manifestation of established disease can be quite long (30-40 years or more), it will be important to continue to monitor recipients of superovulation regimens.

Support for the ovulation-cancer concept comes from observations of intensive egg-laying hens. These animals ovulate nearly every day and progress to carcinomatosis at a high frequency (4-40\% depending on reproductive history and age) (Fredrickson, 1978; Damjanov, 1989; Rodriguez-Burford et al., 2001). Inhibition of ovulation with a progestin protected hens from ovarian cancer (Barnes et al., 2002).

There are essentially no published data on spontaneous rates of ovarian cancer among nonhuman mammals. One would expect incidences to be low because females of most species are either pregnant, lactating, or seasonally-anestrus for most of their reproductive lives. Inclusion bodies of surface epithelium have been reported in ovaries of ewes (Murdoch, 1994). In rodents, ovarian 
surface epithelial stratifications, invaginations, and cysts were related to lifetime ovulations (Clow et al., 2002; Tan et al., 2005) and cycles of ovulation induction or estrogen administration (Celik et al., 2004; Burdette et al., 2006, 2007; Gotfredson and Murdoch, 2007). Advancement to cancer occurred in superovulated rats whose ovaries were exposed to a mutagen (Stewart et al., 2004).

Ovulation has been likened to an acute inflammatory reaction (Espey, 1994). Whether inflammation is involved in ovarian carcinogenesis is a subject of recent attention (Shan and Liu, 2009).

\section{Carcinogenic implication of ovulatory genotoxicity}

Base damages to DNA caused by reactive oxygen species are an inevitable by-product of physiological metabolism. To combat this predicament, animals have evolved elaborate enzymatic antioxidant defense mechanisms (superoxide dismutase, glutathione perioxidase, catalase); however, these are less than perfect, and toxic oxidants find their way to DNA targets (Collins, 1999).

The N7-C8 bond of guanine is particularly susceptible to attack by the unpaired electron of hydroxyradical. Arguably, 8-oxoguanine is the most important mutagenic lesion in DNA; mispairing with adenine during replications can yield GC-to-TA transversions often detected in tumor cells (Grollman and Moriya, 1993; Cunningham, 1997; Fortini et al., 2003). Ovarian surface epithelial cells isolated from the perimeters of ovulated sheep, human, and hen follicles contained concentrations of 8-oxoguanine that exceeded those of cells obtained from extrinsic areas not affected by ovulation (Murdoch et al., 2001, 2005; Murdoch and Martinchick, 2004). Reactive oxidants are generated by leukocytes which are attracted (by fragments of collagen) into the vicinity of the ovulatory stigma and undergo a respiratory burst (Murdoch and McCormick, 1993). Another contributing determinant of genotoxicity is the ischemia-reperfusion flux that coincides with ovulation and wound reparation (Murdoch et al., 1983; Cavender and Murdoch, 1988). Challenges to the genetic integrity of the ovarian surface epithelium were negated by pharmacological ovulation blockade (Murdoch et al., 2001).

A defective tumor suppressor gene, such as those that overexpress competitive mutant forms of the growth-inhibitory BRCA $1 / 2$ or TP 53 , is a probable basis for developing ovarian neoplasia as a result of ovulation (Aunoble et al., 2000; Cvetkovic, 2003). Oxidative damages to guanine persisted in ovine ovarian surface epithelial cells that were affected by ovulation in vivo and in which synthesis of TP53 was then negated in culture by an antisense oligonucleotide; this was related to discordant cellular growth rates and expression of the cancer antigen CA-125 (Murdoch, 2003). Chromosomal anomalies and metaplasia have been detected in repetitive subcultures (to mimic recurrent ovulation-wound repair) of ovarian surface epithelial cells of rodents (Godwin et al., 1992; Roby et al., 2000).

Fortunately, corruptions to DNA instigated by ovulation are normally conciliated by housekeeping cell-cycle arrest and base-excision repair mechanisms. TP53 allots the time required for repair and proof-reading (Vousden and LU, 2002). Polymerase $B$ performs the penultimate gap-filling function in the short-patch pathway (Fortini et al., 2003; Sung and Demple, 2006). TP53 and polymerase B were up-regulated in response to the oxidative stress of ovulation imposed upon the ovarian surface epithelium of sheep (Murdoch et al., 2001). Production of TP53 and polymerase B were enhanced by progesterone (Murdoch an Van Kirk, 2002). Progesterone also stimulated poly(ADP-ribose) polymerase (PARP) in ovine cells (Murdoch, 1998b). Poly(ADP-ribose) polymerase serves as an adjunct in DNA repair. Binding of PARP and synthesis of branched polymers of ADP-ribose in areas adjacent to a single-strand interruption functions as an antirecombinogenic element (Lindahl and Wood, 1999). Progesterone inhibited 
proliferation (Wright et al., 2002) and induced apoptosis (Rodriguez, 2003) in cultures of ovarian surface epithelial cells of macaques. The cells of the ovarian epithelium bordering postovulatory follicles of hens (which do not form a corpus luteum) undergo apoptosis and are resorbed during follicular atresia (Murdoch et al,, 2005). Ovarian inclusion bodies of surface epithelium can evidently be eliminated via the Fas apoptotic system (Ghahremani et al., 1999).

\section{Antioxidants and ovarian cancer prophylaxis?}

There is epidemiological evidence suggesting an inverse relationship between consumption of the antioxidant vitamin $\mathrm{E}$ and risk of ovarian carcinoma (Fairfield et al., 2001; McCann et al., 2001). Similar reports have advocated protective effects of vitamin $E$ against cancers of the lung, colorectum, cervix, and prostate gland (Tamini et al., 2002). It appears that in general incidences of oxidative DNA lesions and susceptibility to cancer are potentiated by micronutrient (e.g., antioxidant vitamin) deficiencies (Ames and Wakimoto, 2002). The circulatory antioxidant status of ovarian cancer patients was reduced compared to age-matched controls (Senthil et al., 2004).

DNA of ovarian surface epithelial cells associated with the ovulation stigma of ewes was protected from oxidative base damage by pretreatment with natural-source vitamin E; programmed death within the surface epithelium, ovulation, and pregnancy outcome were not affected (Murdoch and Martinchick, 2004). Oxoguanine-positive surface cells of gonadotropin-primed/ superovulated ewes treated with the tumor suppressor disruptor dimethylbenzanthracene and the mitogen estradiol-17ß hypersecreted UPA and formed ovarian inclusion cysts containing proliferative epithelium; these responses were circumvented by pretreatment with vitamin $E$ (Murdoch et al., 2008). Ischemia-reperfusion injury to grafts of ovarian tissues was reduced by vitamin $\mathrm{E}$ (Nugent et al., 1998).

Vitamin $E$ is an effective chain-breaking antioxidant in cellular membranes and thereby contributes to membrane phospholipid stability and safeguards intracellular molecules against damage caused by free radicals (Herrera and Barbas, 2001). Vitamin E also can act via mechanisms beyond its oxidant-quenching properties (Kline et al., 2001; Azzi et al., 2002). Nitric oxide production by endothelial cells and superoxide release by leukocytes were suppressed by vitamin $E$. Nonredox modes of $\alpha$-tocopherol action include inhibitory and stimulatory effects on rates of mitosis and removal of damaged DNA, respectively. Therefore, vitamin $E$ could act during the postovulatory period to impede untoward proliferative responses of ovarian surface epithelial cells until repairs to DNA can be accomplished.

\section{Ovulation and ovarian cancer: Model and additional considerations}

The DNA of ovarian surface epithelial cells contiguous with the site of ovulation is compromised by oxyradicals. It is proposed that this constitutes a first step in the etiology of ovarian tumorigenesis (Figure 2). To fend off accumulations of potentially harmful mutations it is essential that accurate restoration or proficient removal of anomalous cells occurs. The level of danger hence escalates when a cell (as a prelude to mutation) averts (due to a malfunctional tumor suppressor) repair or death. Perhaps the ovarian epithelium is vulnerable to genetic damages that are not reconciled because it has not been under evolutionary pressure to respond to superfluous ovulations (Auersperg et al., 1998). Lifetime ovulations in most animals are kept to a minimum by pregnancy and anestrus.

It remains uncertain why, in particular, the ovarian surface epithelium is so prone to neoplastic transformation; after all, it represents only a small fraction of the diverse cell-types that populate 
the ovary. Susceptibility may hinge on the fact that (normal) ovarian surface epithelial cells are of an uncommitted phenotype. Unlike the Mullerian epithelia of the female reproductive tract, development of ovarian surface cells is arrested at an immature pluripotent/stem stage (Auersperg et al., 2001).

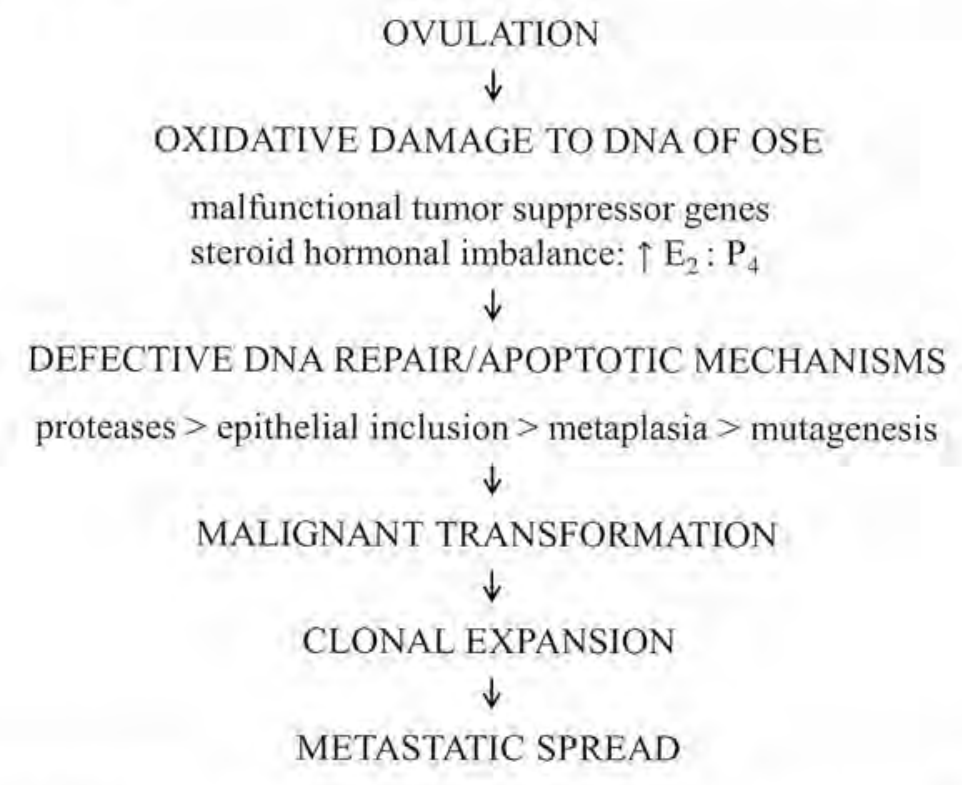

Fig. 2. Hypothetical role of ovulation in the chronology of epithelial ovarian cancer. $E_{2}$, estradiol.

The sequences of events that lead to common ovarian cancer are multifactorial. Several aberrant phases are undoubtedly required to yield a malignant phenotype with distinct growth and metastatic advantages (Figure 2). Ovarian cancer is generally considered to have some level of hormonal involvement; progestins are protective and gonadotropins, androgens, and estrogens are facilitative (Salehi et al., 2008). Paracrine-autocrine modulators (growth factors and cytokines) can also influence ovarian cancer cell behaviors (Auersperg et al., 2001). Metastatic spread is protease-dependent; urokinase and downstream matrix metalloproteinases, that digest basement membranes and interstitial connective tissues, are of particular importance (McDonnel Smedts et al., 2005). Vascular endothelial growth/permeability factor is secreted by ovarian cancer cells and has been related to ascites formation and metastasis (Bamberger and Perrett, 2002).

Because the prognosis for ovarian cancer patients with metastatic disease is so poor, and early detection has proven elusive, it is imperative that methods of chemoprevention be explored. Perhaps supplemental vitamin E could be of value to individuals at risk for the development of ovarian cancer (e.g., those with a genetic predisposition who are not using a contraceptive that inhibits ovulation).

It is important to emphasize in closing that a correlative association between ovulation and the initiation of common ovarian cancer does not prove causal effect and that an "ovulation model" is not absolute and does not explain the genesis of all epithelial ovarian tumors, For example: protection is conferred by tubal ligation or hysterectomy in spite of uninterrupted ovulation; protection provided by one gestation with breast feeding or short-term oral contraceptive use is superior to the predicted benefits of those missed ovulations that would have occurred; reduced numbers of ovulatory cycles due to menstrual irregularities and infertility (e.g., 
polycystic ovarian syndrome) are independent risk factors for ovarian cancer; and in addition to ovulation, other inflammatory responses (endometriosis and exposure of the ovarian surface to exogenous irritants such as talc, pesticides, or viruses) have been linked to ovarian cancer (Holschneider and Berek, 2000; Ness et al., 2000; Salehi et al., 2008; Shan and Liu, 2009).

\section{References}

Ames BN, Wakimoto P 2002 Are vitamins and mineral deficiencies a major cancer risk? Nature Reviews Cancer 2 694-704.

Andreasen PA, Egelund R, Petersen HH 2000 The plasminogen activation system in tumor growth, invasion, and metastasis. Cellular and Molecular Life Sciences $5725-40$.

Aunoble B, Sanches R, Didier E, Bignon YJ 2000 Major oncogenes and tumor suppressor genes involved in epithelial ovarian cancer. International Journal of Oncology 16 567-576.

Auersperg N, Edelson MI, Mok SC, Johnson SW, Hamilton TC 1998 The biology of ovarian cancer. Seminars in Oncology 25 281-304.

Auersperg N, Wong AST, Choi KC, Kang SK, Leung PCK 2001 Ovarian surfacẻ epithelium: biology, endocrinology, and pathology. Endocrine Reviews 22 255-288,

Azzi A, Ricciarelli R, Zingg JM 2002 Non-antioxidant molecular functions of alpha-tocopherol (vitamin E). FEBS Letters 519 8-10.

Baker T, Reddy E 1996 Transducers of life and death: TNF receptor superfamily and associated proteins. Oncogene 12 1-9.

Balbin M, Fueyo A, Lopez JM, Diez-Itza I, Velasco G, Lopez-Otin C 1996 Expression of collagenase-3 in the rat ovary during the ovulatory process. Journal of Endocrinology 149 405-415.

Bamberger ES, Perrett CW 2002 Angiogenesis in epithelial ovarian cancer. Molecular Pathology 55 348-359.

Bandera CA 2005 Advances in understanding of risk factors of ovarian cancer. Journal of Reproductive Medicine $50399-406$.

Barnes MN, Berry WD, Straughn JM, Kirby TO, Leath CA, Huh WK, Grizzle WE, Partridge EE 2002 A pilot study of ovarian cancer chemoprevention using medroxyprogesterone acetate in an avian model of spontaneous ovarian carcinogenesis. Gynecologic Oncology 87 57-63.

Bjersing L, Cajander S 1975 Ovulation and the role of the ovarian surface epithelium. Experentia 31 605-608.

Black RA, Rauch CT, Kozlosky CJ, Peschon JJ, Slack JL, Wolfson MF, Castner BJ, Stocking KL, Reddy P, Srinivasan S, Nelson N, Boiani N, Schooley KA, Gerhart M, Davis R, Fitzner JN, Johnson RS, Paxton RJ, March C], Cerretti DP 1997 A metalloproteinase disintegrin that releases tumour necrosis factor- $\alpha$ from cells. Nature 385 729-733.

Brannstrom M, Bonello N, Wang LJ, Norman RJ 1995 Effects of tumour necrosis factor $a$ on ovulation in the rat ovary. Reproduction Fertility and Development 7 $67-73$.

Bridges PJ, Fortune JE 2007 Regulation, action and transport of prostaglandins during the periovulatory period in cattle. Molecular and Cellular Endocrinology 263 1-9.

Burdette JE, Kurley SJ, Kilen SM, Mayo KE, Woodruff TK 2006 Gonadotropin-induced superovulation drives ovarian surface epithelia proliferation in CD1 mice. Endocrinólogy 147 2338-2345.

Burdette JE, Oliver RM, Ulyanov V, Kilen SM, Mayo KE, Woodruff TK 2007 Ovarian epithelial inclusion cysts in chronically superovulated CD1 and Smad2 dominantnegative mice, Endocrinology 148 3595-3604.

Butler TA, Zhu C, Mueller RA, Fuller GC, LeMaire WJ, Woessner JF 1991 Inhibition of ovulation in the perfused rat ovary by the synthetic collagenase inhibitor SC 44463. Biology of Reproduction 44 1183-1188.

Carvalho CB, Yeik BS, Murdoch WJ 1989 Significance of folicular cyclooxygenase and lipoxygenase pathways of metabolism of arachidonate in sheep. Prostaglandins 37 553-558.

Cavender IL, Murdoch WJ 1988 Morphological studies of the microcirculatory system of periovulatory ovine follicles. Biology of Reproduction 39 989-997.

Celik C, Gezginc K, Aktan M, Acar A, Yaman ST, Gungor S, Akyurek C 2004 Effects of ovulation induction on ovarian morphology: an animal study, International Journal of Gynecological Cancer 14 600-606.

Chene G, Penault-Llorca F, Le Bouedec G, Mishellany F, Dauplat MM, Jaffeux P, Aublet-Cuvelier B, Pouly IL, Dechelotte P, Dauplat J 2009 Ovarian epithelial dysplasia after ovulation induction: time and dose effects. Human Reproduction 24 132-138.

Clow OL, Hurst PR, Fleming JS 2002 Changes in the mouse ovarian surface epithelium with age and ovulation number. Molecular and Cellular Endocrinology $191105-111$.

Colgin DC, Murdoch WI 1997 Evidence for a role of the ovarian surface epithelium in the ovulatory mechanism of the sheep: secretion of urokinase-type plasminogen activator. Animal Reproduction Science 47 197-204.

Collins AR 1999 Oxidative DNA damage, antioxidants, and cancer. Bioessays 21 238-246.

Cunningham RP 1997 DNA repair: caretakers of the genome. Current Biology 7 R576-579.

Curry TE, Smith MF 2006 Impact of extracellular matrix remodeling on ovulation and the folliculo-luteal transition. Seminars in Reproductive Medicine 24 228-241.

Cvetkovic D 2003 Early events in ovarian oncogenesis. Reproductive Biology and Endocrinology 168.

Damjanov 11989 Ovarian tumours in laboratory and domestic animals. Current Topics in Pathology $781-10$.

deMola JRL, Goldfarb JM, Hecht BR, Baumgardner GP, Babbo CJ, Friedlander MA 1998 Gonadotropins induce the release of interleukin-1, interleukin-6 and tumor 
necrosis factor- $\alpha$ from the human preovulatory follicle. American Journal of Reproductive Immunology 39 387-390.

Driancourt MA, Quesnel H, Meduri G, Prunier A, Hermier D 1998 Luteinization and proteolysis in ovarian follicles of Meishan and Large White gilts during the preovulatory period. Journal of Reproduction and Fertility 114 287-297.

Endo HHT, Nagasawa K, Hayashi T, Chida M, Akutagawa N, Iwasaki M, Kitajima Y, Kiya T, Nishikawa A, Manase K, Kudó R 2001 Lysyl oxidase and MMP-2 expression in dehydroepiandrosterone-induced polycystic ovary in rats. Biology of Reproduction 64 157-162.

Espey LL 1994 Current status of the hypothesis that mammalian ovulation is comparable to an inflammatory reaction. Biology of Reproduction 50 233-238.

Fairfield KM, Hankinson SE, Rosner BA, Hunter DJ, Colditz GA, Willett WC 2001 Risk of ovarian carcinoma and consumption of vitamins $A, C$, and $E$ and specific carotenoids. Cancer 92 2318-2326.

Fathalla MF 1971 Incessant ovulation - a factor in ovarian neoplasia? Lancet 2163.

Feeley KM, Wells M. 2001 Precursor lesions of ovarian epithelial malignancy. Histopathology 38 87-95.

Fortini P, Pascucci B, Parlanti E, D'Errico M, Simonelli V, Dogliotti E 2003 8-Oxoguanine DNA damage: at the crossroad of alternative repair pathways. Mutation Research 531 127-139.

Fredrickson IN 1978 Ovarian tumors of the hen. Environmental Health Perspective 73 35-51.

Fukumoto M, Yajima Y, Okamura H, Midorikawa O 1981 Collagenolytic enzyme activity in human ovary: an ovulatory enzyme system. Fertility and Sterility 36 746-750.

Ghahremani M, Foghi A, Dorrington JH 1999 Etiology of ovarian cancer: a proposed mechanism. Medical Hypotheses 52 23-26.

Godwin AK, Testa JR, Handel LM, Liu Z, Vanderveer LA, Tracey PA, Hamilton TC 1992 Spontaneous transformation of rat ovarian surface epithelial cells: association with cytogenetic changes and implications of repeated ovulation in the etiology of ovarian cancer. lournal of the National Cancer Institute 84 592-601.

Gotfredson GS, Murdoch WJ 2007 Morphologic responses of the mouse ovarian surface epithelium to ovulation and steroid hormonal milieu. Experimental Biology and Medicine 232 277-280.

Gottsch ML, Van Kirk EA, Murdoch WJ 2000 Tumour necrosis factor $\alpha$ up-regulates matrix metalloproteinase-2 activity in periovulatory ovine follicles: metamorphic and endocrine implications. Reproduction, Fertility and Development 12 75-80.

Grollman AP, Moriya M 1993 Mutagenesis by 8-oxoguanine: an enemy within. Trends in Genetics 9 246-249.

Hagglund AC, Ny A, Liu K, Ny T 1996 Coordinated and cell-specific induction of both physiological plasminogen activators creates functionally redundant mechanisms for plasmin formation during ovulation. Endocrinology 137 5671-5677

Halterman SD, Murdoch WI 1986 Ovarian function in ewes freated with antihistamines. Endocrinology 119 2417-2421.

Hamilton TC 1992 Ovarian cancer, biology. Current Problems in Cancer 16 5-57.

Herrera E, Barbas C 2001 Vitamin E: action, metabolism and perspectives. loumal of Physiology and Biochemistry 57 43-56.

Holschneider CH, Berek JS 2000 Ovarian cancer: epidemiology, biology, and prognostic factors. Seminars in Surgical Oncology 19 3-10.

Jo M, Thomas LE, Wheeler SE, Curry TE 2004 Membrane type 1-matrix metalloproteinase (MMP)-associated MMP-2 activation increases in the rat ovary in résponse to an ovulatory dose of human chorionic gonadotropin. Biology of Reproduction 70 1024-1032.

Johnson ML, Murdoch J, Van Kirk EA, Kaltenbach JE, Murdoch WJ 1999 Tumor necrosis factor $\alpha$ regulates collagenolytic activity in preovulatory ovine follicles: relationship to cytokine secretion by the oocytecumulus cell complex. Biology of Reproduction 61 1581-1585

Kline K, Yu W, Sanders BG 2001 Vitamin E: mechanisms of action as tumor cell growth inhibitors. Journal of Nutrition 131 161S-1635.

Komar CM, Matousek M, Mitsube K, Mikuni $M$, Brannstrom M, Curry TE 2001 Effects of genistein on the periovulatory expression of messenger ribonucleic acid for matrix metalloproteinases and tissue inhibitors of metalloproteinases in the rat ovary. Reproduction 121 259-265.

Kurusu S, Jinno M, Ehara H, Yonezawa T, Kawaminami M 2009 Inhibition of ovulation by a lipoxygenase inhibitor involves reduced cyclooxygenase-2 expression and prostaglandin E2 production in gonadotropin-primed immature rats. Reproduction 137 59-66.

Larrick JW, Wright SC 1990 Cytotoxic mechanism of tumor necrosis factor- $\alpha$. FASEB Journal 4 3215-3223.

LeBleu VS, Macdonald B, Kalluri R 2007 Structure and function of basement membranes. Experimental Biology and Medicine 232 1121-1129.

LindahI T, Wood RD 1999 Quality control by DNA repair. Science 286 1897-1905.

Liu X, Wu H, Byrne M, Jeffrey J, Krane S, Jaenisch R 1995 A targeted mutation at the known collagenase cleavage site in mouse type l collagen impairs tissue remodelling. lournal of Cell Biology $130227-237$.

Luck MR 1994 The gonadal extracellular matrix. Oxford Reviews of Reproductive Biology 16 34-85.

Mahdavi A, Pejovic T, Nezhat F 2006 Induction of ovulation and ovarian cancer: a critical review of the literature. Fertility and Sterility $\mathbf{8 5}$ 819-826.

McCann SE, Moysich KB, Mettlin C 2001 Intakes of selected nutrients and food groups and risk of ovarian cancer. Nutrition and Cancer 39 19-28.

McDonnel Smedis A, Curry TE, Murdoch WI 2005 Proteolytic enzymes and their inhibition in epithelial ovarian cancer. Current Enzyme Inhibition 1 157-170.

Murdoch J, Van Kirk EA, Murdoch WJ 1999 Hormonal control of urokinase plasminogen activator secretion by sheep ovarian surface epithelial cells. Biology of 
Reproduction 61 1487-1491.

Murdoch WJ 1988 Disruption of cellular associations within the granulosal compartment of periovulatory ovine follicles: relationship to maturation of the oocyte and regulation by prostaglandins. Cell and Tissue Research 252 459-462.

Murdoch WJ 1994 Ovarian surface epithelium during ovulatory and anovulatory ovine estrous cycles. Anatomical Record 240 322-326.

Murdoch WJ 1995a Programmed cell death in preovulatory ovine follicles. Biology of Reproduction 53 8-12.

Murdoch WJ 1995b Endothelial cell death in preovulatory ovine follicles: possible implication in the biomechanics of rupture. Journal of Reproduction and Fertility 105 161-164.

Murdoch WJ 1998a Regulation of collagenolysis and cell death by plasmin within the formative stigma of preovulatory ovine follicles. Joumal of Reproduction and Fertility $113331-336$.

Murdoch WJ 1998b Perturbation of sheep ovarian surface epithelial cells by ovulation: evidence for roles of progesterone and poly(ADP-ribose) polymerase in the restoration of DNA integrity. Journal of Endocrinology 156 503-508.

Murdoch WI 2000 Proteolytic and cellular death mechanisms in ovulatory ovarian rupture. Biological Signals. and Receptors 9 102-114.

Murdoch WJ 2003 Metaplastic potential of p53 downregulation in ovarian surface epithelial cells affected by ovulation. Cancer Letters 191 75-81.

Murdoch WJ 2008 Ovulatory factor in ovarlan carcinogenesis. Advances in Experimental Medicine and Biology 622 119-128.

Murdoch W], Farris ML 1988 Prostaglandin E,-9-ketoreductase activity of preovulatory ovine follicles. lournal of Animal Science 66 2924-2929.

Murdoch WJ, Martinchick JF 2004 Oxidative damage to DNA of ovarian surface epithelial cells affected by ovulation: carcinogenic implication and chemoprevention. Experimental Biology and Medicine 229 553-559.

Murdoch WJ, McCormick RJ 1992 Enhanced degradation of collagen within apical vs. basal wall of ovulatory ovine follicle. American lournal of Physiology 263 E221-E225.

Murdoch WJ, McCormick RJ 1993 Mechanisms and physiological implications of leucocyte chemoattraction into periovulatory ovine follicles. Journal of Reproduction and Fertility 97 375-380.

Murdoch WJ, Van Kirk EA 2002 Steroid hormonal regulation of proliferative, p53 tumor suppressor, and apoptotic responses of sheep ovarian surface epithelial cells. Molecular and Ceflular Endocrinology 186 61-67.

Murdoch WI, Colgin DC, Ellis JA 1997 Role of tumor necrosis factor-a in the ovulatory mechanism of ewes. lournal of Animal Science 75 1601-1605.

Murdoch WJ, Hansen TR, McPherson LA 1993 Role of eicosanoids in vertebrate ovulation. Prostaglandins. $4685-115$.

Murdoch WJ, Nix KJ, Dunn TG 1983 Dynamics of ovarian blood supply to periovulatory follicles of the ewe.
Biology of Reproduction 28 1001-1006.

Murdoch W], Peterson TA, Van Kirk EA, Vincent DL, Inskeep EK 1986 Interactive roles of progesterone, prostaglandins and collagenase in the ovulatory mechanism of the ewe. Biology of Reproduction 35 1187-1194.

Murdoch WJ, Townsend RS, McDonnel AC 2001 Ovulation-induced DNA damage in ovarian surface epithelial cells of ewes: prospective regulatory mechanisms of repair/survival and apoptosis. Biology of Reproduction 65 1417-1424.

Murdoch W], Van Kirk EA, Alexander BM 2005 DNA damages in ovarian surface epithelial cells of ovulatory hens. Experimental Biology and Medicine 230 429-433.

Murdoch WJ, Van Kirk EA, Murdoch J 1999a Plasmin cleaves tumor necrosis factor $\alpha$ exodomain from sheep follicular endothelium: implication in the ovulatory process. Biology of Reproduction 60 1166-1171.

Murdoch WJ, Van Kirk EA, Shen Y 2008 Pathogenic reactions of the ovarian surface epithelium to ovulation, dimethylbenzanthracene, and estrogen are negated by vitamin E. Reproductive Sciences 15 839-845.

Murdoch WJ, Wilken C, Young DA 1999 b Sequence of apoptosis and inflammatory necrosis within the formative ovulatory site of sheep follicles. Journal of Reproduction and Fertility 117 325-329.

Nagase H, Woessner JF 1999. Matrix metalloproteinases. lournal of Biological Chemistry 274 21491-21494.

Nagyova E, Nemcova L, Prochazka R 2009 Expression of tumor necrosis factor alpha-induced protein 6 messenger RNA in porcine preovulatory ovarian follicles. Journal of Reproduction and Development $\mathbf{5 5}$ 231-235.

Ness RB, Grisso JA, Cottreau C, Klapper J, Vergona R, Wheeler JE, Morgan M, Schlesselman If 2000 Factors related to inflammation of the ovarian epithelium and risk of ovarian cancer. Epidemiology 11 111-117.

Nugent D, Newton H, Gallivan L, Gosden RG 1998 Protective effect of vitamin $\mathrm{E}$ on ischaemia-reperfusion injury in ovarian grafts. Journal of Reproduction and Fertility 114 341-346.

Peng XR, Hsueh AJW, Ny T 1993 Transient and cellspecific expression of tissue-type plasminogen activator and plasminogen activator-inhibitor type 1 results in controlled and directed proteolysis during gonadotropin-induced ovulation. European Journal of Biochemistry 214 147-156.

Purdie DM, Bain Cl, Siskind V, Webb PM, Green AC 2003 Ovulation and risk of epithelial ovarian cancer. International lournal of Cancer 104 228-232.

Reich R, Tsafriri A, Mechanic GL 1985 The involvement of collagenolysis in ovulation in the rat. Endocrinology 116 522-527.

Riley SC, Gibson AH, Leask R, Mauchline DJW, Pedersen HG, Watson ED 2001 Secretion of matrix metalloproteinases 2 and 9 and tissue inhibitor of metalloproteinases into follicular fluid during follicle development in equine ovaries. Reproduction 121 553-560.

Roberts AJ, Dunn TG, Murdoch WJ 1985 Induction of ovulation in proestrous ewes: identification of the ovulatory follicle and functional status of the corpus luteum. Domestic Animal Endocrinology 2 207-210. 
Robker RL, Russell DL, Yoshioka S, Sharma SC, Lyndon JP, O'Malley BW, Espey LL, Richards IS 2000 Ovulation: a multi-gene, multi-step process. Steroids $\mathbf{6 5} 559-570$.

Roby KF, Son DS, Terranova PF 1999 Alterations of events related to ovarian function in tumor necrosis factor receptor type I knockout mice. Biology of Reproduction 61 1616-1621.

Roby KF, Taylor CC, Sweetwood IS, Cheng Y, Pace IL, Tawfik O, Persons DL, Smith PG, Terranova PF 2000 Development of a syngeneic mouse model for events related to ovarian cancer. Carcinogenesis 21 585-591.

Rodriguez G 2003 New insights regarding pharmacologic approaches for ovarian cancer prevention. Hematology/ Oncology Clinics of North America 17 1007-1020.

Rodriguez-Burford C, Barnes MN, Berry W, Partridge EE, Grizzle WE 2001 Immunohistochemical expression of molecular markers in an avian model: a potential model for preclinical evaluation of agents for ovarian cancer chemoprevention. Gynecologic Oncology $\mathbf{8 1}$ 373-379.

Salehi F, Dunfield L, Phillips KP, Krewski D, Vanderhyden BC 2008 Risk factors for ovarian cancer: an overview with emphasis on hormonal factors, Journal of Toxicology and Environmental Health, Part B: Critical Reviews 11 301-321.

Sayasith K, Dore M, Sirois J 2007 Molecular characterization of tumor necrosis alpha-induced protein 6 and its human chorionic gonadotropin-dependent induction in theca and mural granulosa cells of equine preovulatory follicles. Reproduction 133 135-145.

Senthil K, Aranganathan S, Nalini N 2004 Evidence of oxidative stress in the circulation of ovarian cancer patients. Clinica Chimica Acta 339 27-32.

Shan W, Liu J 2009 Inflammation: a hidden path to breaking the spell of ovarian cancer. Cell Cycle $83107-3111$

Shoulders MD, Raines RT 2009 Collagen structure and stability. Annual Review of Biochemistry 78 929-958.

Smokovitis A, Kokolis N, Alexaki-Tzivanidou E 1988 The plasminogen activator activity is markedly increased mainly at the area of the rupture of the follicular wall at the time of ovulation. Animal Reproduction Science 16 285-294.

Stewart SL, Querec TD, Ochman AR, Gruver BN, Bao R, Babb JS, Wong TS, Koutroukides T, Pinnola AD, Klein-Szanto A, Hamilton TC, Patriotis C 2004 Characterization of a carcinogenesis rat model of ovarian preneoplasia and neoplasia. Cancer Research $648177-8183$.

Sung IS, Demple B 2006 Roles of base excision repair subpathways in correcting oxidized abasic sites in DNA. FEBS lournal 273 1620-1629.

Tadakuma H, Okamura H, Kitaoka M, Iyama K, Usuku G 1993 Association of immunolocalization of matrix metalloproteinase 1 with ovulation in hCG-treated rabbit ovary. Journal of Reproduction and Fertility 98 503-508.

Talbot P, Martin GG, Ashby H 1987 Formation of the rupture site in preovulatory hamster and mouse follicles: loss of surface epithelium. Gamele Research $17287-302$.

Tamini RM, Lagiou P, Adami HO, Trichopoulos D 2002 Prospects for chemoprevention of cancer. lournal of Internal Medicine 251 286-300.

Tan OL, Hurst PR, Fleming IS 2005 Location of inclusion cysts in mouse ovaries in relation to age, pregnancy, and total ovulation number: implications for ovarian cancer? Journal of Pathology 205 483-490.

Terranova PF 1997 Potential roles of tumor necrosis factor- $\alpha$ in follicular development, ovulation, and the life span of the corpus luteum. Domestic Animal Endocrinology 14 1-15.

Tung KH, Wilkens LR, Wu AH, McDuffie K, Nomura AM, Kolonel LN, Terada KY, Goodman MT 2005 Effect of anovulation factors on pre and postmenopausal ovarian cancer risk: revisiting the incessant ovulation hypothesis. American Journal of Epidemiology 161 321-329.

Valko M, Izakovic M, Mazur M, Rhodes CI, Tesler J 2004 Role of oxygen radicals in DNA damage and cancer incidence. Molecular and Cellular Biochemistry 266 37-56.

Vousden KH, Lu X 2002 Live or let die: the cell's response to p53. Nature Reviews Cancer 2 595-604.

Wilken C, Van Kirk EA, Slaughter RG, Ji TH, Murdoch WJ 1990 Increased production of ovarian thromboxane in gonadotropin-treated immature rats: relationship to the ovulatory process. Prostaglandins 40 637-646.

Wright JW, Toth-Fejel S, Stouffer RL, Rodland KD 2002 Proliferation of rhesus ovarian surface epithelial cells in culture: lack of mitogenic response to steroid or gonadotropic hormones. Endocrinology 143 2198-2207.

Vang WL, Godwin AK, Xu XX 2004 Tumor necrosis factoralpha-induced matrix proteolytic enzyme production and basement membrane remodeling by human ovarian surface epithelial cells: molecular basis linking ovulation and cancer risk. Cancer Research 64 1534-1540.

Yoshioka S, Ochsner S, Russell DL, Ujioka T, Fujii S, Richards JS, Espey LL 2000 Expression of tumor necrosis factor-stimulated gene- 6 in the rat ovary in response to an ovulatory dose of gonadotropin. Endocrinology $1414114-4119$.

Zalanyi S 2001 Progesterone and ovulation. European lournal of Obstetrics and Gynecology and Reproductive Biology 98 152-159. 